\title{
O ESTATUTO CONCEITUAL DO INCONSCIENTE EM FREUD E ALGUMAS DE SUAS IMPLICAÇÕES PARA A PRÁTICA PSICANALÍTICA ${ }^{*}$
}

Helio Honda

Helio Honda

Professor do

Departamento

de Psicologia e

do Programa de

Pós-Graduação

em Psicologia

da Universidade

Estadual de Maringá

(PR).

RESUMO: Trata-se da relação entre clínica e metapsicologia, tomando como objeto de análise as bases metodológicas que articulam o conceito de inconsciente e a prática clínica nele fundada. O psiquismo inconsciente, entendido como objeto da psicanálise, só pode ser apreendido pela trama científico-conceitual forjada por Freud, a metapsicologia. Nessa perspectiva, a orientação da prática psicanalítica dependeria da concepção que o analista tem do inconsciente.

Palavras-chave: Metapsicologia, inconsciente, prática psicanalítica.

ABSTRACT: Conceptual status of the unconscious in Freud and some of its implications for psychoanalytic practice. The article deals with the relationship between clinical and metapsychology, taking as object of analysis the methodological bases that articulate the concept of the unconscious and clinical practice based on it. It is argued that the unconscious psychism understood as the object of psychoanalysis, can only be apprehended by the scientific and conceptual network constructed by Freud, the metapsychology. From this perspective, the stance of psychoanalytic practice would depend on the conception that the analyst has of the unconscious.

Keywords: Metapsychology, unconscious, psychoanalytic practice.

\footnotetext{
* Trabalho vinculado ao Projeto de Pesquisa financiado pelo CNPq Proc. n. 401857/2008-5.
} 
$\Gamma$ rata-se de analisar o problema da relação entre prática e teoria em psicanálise. A hipótese a ser desenvolvida é a de que o manejo da técnica psicanalítica e o papel que o analista se atribui na clínica dependem de sua concepção acerca da realidade psíquica inconsciente, seja esta realista de um Inconsciente individual, seja como predominantemente instrumentalista ou nominalista de um inconsciente único emanado da situação analítica. Cumpre esclarecer, porém, que dado o caráter metodológico da discussão e o recorte específico do objeto de estudo deste artigo, em torno de uma relação — os pressupostos epistemológicos e metodológicos que em Freud articulam o estatuto conceitual do inconsciente e a prática analítica nele fundada — - a exposição não se detém na análise específica das propriedades do Inconsciente como sistema, mas tem como foco os fundamentos metapsicológicos e a demonstração de sua gênese conceitual. O mesmo ocorre com a questão da técnica: limitamo-nos a ilustrá-la mediante a exploração de alguns aspectos da interpretação implicadas com a concepção de Inconsciente em que se apoia.

A discussão está organizada em quatro seções. De início, procuramos evidenciar o caráter eminentemente científico-conceitual, segundo o modo inferencial com que Freud constrói o conceito de Inconsciente. Em seguida, reconstruímos a argumentação freudiana relativa à insuficiência das teorias médicas vigentes e o modo como justifica a necessidade de construir uma teoria psicológica nova que leve em conta os processos psíquicos inconscientes na explicação das perturbações mentais. Na seção três, analisamos alguns aspectos do processo da repressão primordial [Urverdrängung], ${ }^{1}$ a fim de esclarecer como Freud demonstra a gênese conceitual do Inconsciente. Na última seção, a partir do contraponto de duas concepções distintas sobre o Inconsciente - a de Laplanche e a de Nasio - analisamos algumas das implicações para a prática clínica decorrentes do tipo de concepção de Inconsciente que se adota.

\section{A ASPIRAÇÃO CIENTÍFICA DA CONCEITUAÇÃO FREUDIANA}

Qual poderia ser o estatuto de uma teorização cujos conceitos tratam de uma realidade que escapa totalmente à percepção e ao conhecimento imediato pela consciência? Como compreender a elaboração de um conceito, cuja referência não é logo perceptível, nem pode ser observado diretamente pelos recursos habi-

\footnotetext{
${ }^{1}$ Convém esclarecer que o termo dominante no meio psicanalítico em nosso país, talvez influenciado pela leitura francesa veiculada, sobretudo, por Laplanche e Pontalis (1967), para traduzir o alemão Urverdrängung é "recalque originário" ou "recalcamento originário", e Verdrängung por "recalque" ou "recalcamento". Porém, neste artigo e em nossa leitura da obra de Freud acompanhamos os argumentos formulados por Paulo Cesar de Souza (1998) em favor da opção por "repressão" para traduzir Verdrängung e, por extensão, "repressão primordial” para Urverdrängung.
} 
tuais? Afinal, a crença dominante era a de que nas ciências empíricas os conceitos são forjados e igualmente validados a partir da observação dos fatos. A crítica epistemológica às pretensões da ciência ensinou-nos, porém, que a crença indutivista não se sustenta frente à análise lógica, além de ter demonstrado que certas intuições teóricas precedem a observação, ou seja, que, no fundo, é a teoria que orienta a experiência que temos da realidade (CHALMERS, 1976/1982). Apesar disso, a dificuldade tende a persistir se não atentarmos para o modo inferencial com que Freud constrói os conceitos que formam a metapsicologia - dentre eles, o conceito relativo ao objeto da psicanálise, o Inconsciente.

Porém, ao nos voltarmos para o sentido da revolução conceitual produzida pelo advento da ciência moderna nos séculos XVII e XVIII, com Galileu e Newton, compreendemos que o discurso científico passou a falar da realidade física numa linguagem nova, quase incompreensível pelos falantes do idioma sensualista aristotélico, dominante até a aurora da modernidade. Grosso modo, a explicação aristotélica da realidade física era baseada em princípios causais, como o de finalidade ou teleologia, e, sobretudo, na percepção dos fenômenos pelos próprios sentidos. Assim, explicava-se o fato da fumaça subir, porque seria de sua natureza buscar as partes altas, enquanto que uma pedra lançada para cima volta ao chão por ser esse o seu lugar natural. A linguagem da física aristotélica era baseada nos dados obtidos pelos próprios sentidos, ou, dito de outra forma, a realidade observável era explicada num idioma capaz de ser imediatamente compreendido por todos os falantes da língua. A ciência moderna, ao contrário, é considerada moderna justamente porque rompe com essa linguagem sensualista e funda uma nova linguagem para falar da natureza. A voz da nova ciência se expressa matematicamente, porque foi por meio da matemática que Galileu começou a enxergar uma realidade nova, até então inapreensível pelos meios tradicionais. Com isso, o mesmo fenômeno da queda de uma pedra lançada para cima passou a ser explicado mediante conceitos altamente abstratos — como os de matéria e força - postos em relação matemática. Assim, à diferença do aristotelismo, a física moderna dirá que a pedra cai, porque "matéria atrai matéria na razão direta das massas e inversa das distâncias” (ELIA, 2004/2007, p.12; KOYRÉ, 1957/s.d., p.91-110), linguagem que não é compreensível de imediato pelo falante comum. Quer dizer, a física moderna utiliza uma linguagem nova, porque ela nasce para falar de uma realidade nova. E uma compreensão efetiva dessa nova linguagem — e, portanto, a apreensão dessa nova realidade física — , requer o abandono das velhas referências sensualistas, baseadas nos sentidos ordinários, e um alto grau de abstração conceitual, além do uso do recurso matemático.

Na esteira da revolução caracterizada pela ciência moderna, parece-nos clara a intenção científica de Freud e o rigor lógico com que forja os conceitos metapsicológicos. Além disso, a comparação que ele faz da psicanálise com a 
física é recorrente (FREUD, 1915a/1967, p.211; 1933/1961, p.22). Assim, compreendemos que as desconfianças em relação às possibilidades epistemológicas na tematização do Inconsciente resultam de nossa falta de discernimento acerca da natureza lógico-inferencial, tipicamente científico-moderna, com que Freud forja seus conceitos. Falta de discernimento esta talvez resultante dos preconceitos sensualistas que, sem que o percebamos, podem estar operando na base de nossa leitura sobre o Inconsciente em Freud, razão pela qual convém ler algumas de suas palavras: "O médico precisa reservar-se o direito de avançar mediante um processo de inferência [Schlussprozess], do efeito consciente até o processo psíquico inconsciente" (FREUD, 1900/1961, p.617). De maneira análoga à nova linguagem científico-abstrata, baseada na matemática, que possibilita à física moderna apreender uma realidade material imperceptível aos sentidos, também Freud constrói uma nova linguagem científico-abstrata, ao elaborar a metapsicologia, para dar conta da realidade psíquica, também imperceptível ao senso ordinário. Não parece ser à toa que Freud teve cuidado ao forjar um neologismo para batizar o terreno por ele descoberto, ou melhor, construído conceitualmente. "De resto, vou perguntar-lhe seriamente se eu posso usar o nome de metapsicologia para minha psicologia que avança para trás da consciência”, escreve Freud a Fliess, em 10 de março de 1898 (FREUD, 1986, p.329). Por tratar-se de uma realidade conceitualmente construída, acreditamos que a ausência de uma compreensão dos conceitos forjados por Freud - condição sine qua non para o acesso à realidade psíquica e às forças que a habitam - compromete qualquer intervenção terapêutica orientada pela psicanálise. Convém, portanto, examinar ao menos de forma breve quais teriam sido os passos inferenciais percorridos por Freud desde a medicina e neuropatologia até chegar a essa nova realidade psíquica, ou seja, como teria Freud chegado ao terreno da psicologia para, indo além, fundar a metapsicologia.

\section{DO MÉTODO ANATOMOCLÍNICO AO MÉTODO "PSICOCLÍNICO": METAPSICOLOGIA COMO TEORIA PSICOLÓGICA SOBRE O INCONSCIENTE}

Convém lembrar, antes de tudo, que Freud era médico, formado dentro de um paradigma naturalista-organicista, dominante na segunda metade do século XIX. Especialista em neuropatologia, Freud publicara, ao longo dos anos 1890, três trabalhos sobre paralisias cerebrais (1891, 1893 e 1897), sendo o último intitulado “A paralisia cerebral infantil”, contendo cerca de 300 páginas de texto e mais de 400 entradas na lista bibliográfica, de acordo com Strachey (1962/1973, p.256, n.1). Outras opiniões acerca desses trabalhos neurológicos podem ser lidas na biografia de Freud escrita por Jones, segundo o qual, em resenha ao trabalho de 1897, o neurologista suíço Brun escrevera: 
“A monografia de Freud é a mais minuciosa e completa exposição que já se escreveu sobre as paralisias cerebrais infantis. [...] O fato de apenas a bibliografia ocupar quatorze páginas e meia dá ideia do extraordinário domínio sobre o enorme material clínico aqui reunido e criticamente elaborado. Trata-se de uma realização soberba, que sozinha será suficiente para assegurar ao nome de Freud um lugar permanente na neurologia clínica." (JONES, 1953/1989, p.226)

Antes, porém, um dos principais neurologistas da França e sucessor de Charcot, Pierre Marie, diria, sobre a monografia escrita por Freud em 1893: “Essa monografia é inquestionavelmente a mais completa, a mais precisa e séria que já apareceu sobre o confuso problema da displegia cerebral na infância, a respeito do que tão pouco se sabe" (apud JONES, 1953/1989, p.225). Apesar do reconhecimento alcançado e da crítica altamente favorável aos trabalhos sobre neurologia, Strachey (1962/1973, p.245) informa-nos que nesse período Freud já não lhes dava tanto valor, se comparado aos trabalhos sobre as neuroses. Essas indicações devem servir para mostrar que Freud conhecia bem as teorias sobre a anatomia do sistema nervoso.

Vale assinalar também que o método dominante na medicina em que Freud foi educado era o chamado método anatomoclínico, de acordo com o qual as patologias mentais (neuroses, histerias etc.) deveriam ser explicadas por lesões e perturbações funcionais do sistema nervoso. Desta forma, frente aos sintomas, o médico deveria buscar sua explicação nas teorias médicas sobre a estrutura anatômica e funcional do sistema nervoso. Paralisias de certos membros do corpo eram explicadas por lesões em certas regiões do sistema nervoso.

É nesse contexto que Freud publica em 1893 um artigo em francês em que discute o diagnóstico diferencial das paralisias orgânicas e das paralisias histéricas (FREUD, 1893/1964). Nele, Freud retoma as teorias sobre a anatomia do sistema nervoso e o método corrente na neuropatologia da época, que estabeleciam relações entre os diversos segmentos neuroanatômicos e certas consequências funcionais na periferia do corpo, como as paralisias orgânicas. Isso porque há inervações que recobrem a extensão corporal e, dependendo da área em que ocorre a lesão — se em fibras nervosas periféricas ou no córtex cerebral — , podese esperar uma paralisia em determinados membros ou áreas mais extensas do corpo. Assim, no limite, era possível fazer previsões sobre o tipo e o alcance de uma paralisia; e, de modo inverso, se o exame clínico de um paciente revelasse uma paralisia em determinado membro, poder-se-ia inferir o local do sistema nervoso em que talvez houvesse uma lesão.

Uma dificuldade começa a aparecer quando os sintomas apresentados pelos pacientes de Freud escapavam às previsões da anatomia e não se encaixavam em nenhum conhecimento estabelecido sobre o sistema nervoso. Era o caso das 
paralisias histéricas e dos sintomas neuróticos que escapavam à explicação pelas teorias científicas vigentes, não sendo redutíveis às alterações orgânicas do sistema nervoso. Freud (1893/1964) dá o exemplo de uma paciente que, curiosamente, apresentava paralisia restrita ao braço; a mão e o ombro não estavam comprometidos, como era de se esperar de acordo com as regras da anatomia nervosa. Ou seja, como se poderia explicar uma paralisia do braço apenas, se em uma afecção de fundo orgânico também o ombro e a mão — e, dependendo da extensão da lesão, áreas abrangentes do hemisfério corporal e parte da face - deveriam estar afetados? Em suma, como explicar uma paralisia, cuja configuração não se deixava reduzir a nenhuma das teorias médicas existentes?

Entendemos que foi para dar conta desse tipo de problema que Freud partiu para a construção de uma teoria científica nova. E como as teorias da anatomia nervosa eram consideradas coerentes e consistentes, já que tinham sido construídas com base na observação clínica e nas autópsias - enfim, eram teorias bem fundamentadas empiricamente - não era o caso de abandoná-las ou reformulá-las, pois explicavam bem as paralisias orgânicas. Restava apenas uma alternativa: mudar o enfoque e tentar buscar outra explicação para as paralisias não explicadas por aquelas teorias.

Por esse caminho Freud desenvolve suas elaborações teóricas e vai começar a compreender esse tipo de sintoma como o indício de que algo não vai bem na subjetividade do paciente. Subjetividade esta constituída por ideias ou representações — os restos das experiências — que formariam o sistema de memória de cada pessoa. Essas imagens mentais seriam ocupadas ou investidas por algum tipo de energia, inicialmente denominado quantum de afeto ou soma de excitação. Assim, a intensidade de uma lembrança teria a ver com a carga afetiva que a ocupa, sendo esta capaz de fluir no interior do sistema de memória, podendo ser condensada sobre uma única ideia, ou ser retirada de uma e deslocada para outra ideia ou mesmo convertida e transposta para as inervações corporais. Por isso, a causa da paralisia do braço da paciente continuava a ser uma espécie de lesão, não uma lesão anatômica, mas uma "lesão funcional ou dinâmica" (FREUD, 1893/1964, p.51), compreendida como uma alteração na carga afetiva da ideia de braço. Por alguma razão, que precisava ser descoberta com a ajuda da psicoterapia, a imagem mental de braço teria sofrido alguma alteração. A hipótese era a de que tal alteração se deveria ao esvaziamento afetivo da ideia ou representação de braço, em razão de sua associação com lembranças insuportáveis para a paciente. Ou seja, devido ao significado que o braço pode ter adquirido, ao ser relacionado a alguma lembrança insuportável de experiência traumática vivida pela paciente, sua imagem mental teria sofrido repressão [Verdrängung]. Nesse período inicial da teorização freudiana, o mecanismo da repressão teria a ver com a retirada do afeto que ocupa a ideia. Com isso, a ideia de braço deixaria 
de participar dos processos conscientes, tornando-se inconsciente, já que nessa época, Freud atribuía a diferença entre uma ideia consciente e uma inconsciente à intensidade da carga afetiva. No caso da paralisia histérica da paciente, como a representação de braço teria sofrido repressão, estaria “inacessível para o livre jogo das outras associações” (FREUD, 1893/1964, p.53) e, portanto, não participaria mais dos processos associativos conscientes. Assim, tudo se passava como se, para a paciente, o braço não existisse, razão pela qual não conseguia movê-lo. Leiamos o que considera Freud:

“Em todos os casos de paralisia histérica, vemos que o órgão paralisado ou a função abolida está envolvida em uma associação subconsciente ${ }^{2}$ munida de um grande valor afetivo, e pode-se mostrar que o braço torna-se livre tão logo esse valor afetivo seja apagado.” (FREUD, 1893/1964, p.53)

A nova teoria psicológica que começava a ser esboçada por Freud para explicar transtornos inexplicáveis pelas teorias organicistas supunha que, apesar de encontrarem-se inacessíveis para a consciência, essas ideias reprimidas continuavam a exercer influência no psiquismo. Portanto, certas perturbações passavam a ser compreendidas como fundadas não mais em lesões orgânicas do sistema nervoso, mas em processos psíquicos inconscientes. Em outras palavras, assim como o método anatomoclínico ou anatomopatológico permitia supor uma correspondência entre as regras da anatomia nervosa e as formas das paralisias orgânicas, o método "psicoclínico" ou "psicopatológico” em vias de criação

\footnotetext{
${ }^{2}$ Conforme esclarece Strachey (1966/1971, p.171, n.2), este é um dos primeiros e raros usos que faz Freud do termo subconsciente, ao invés de inconsciente, como faz ao longo da obra. Talvez esse uso se deva ao fato de que, além de ter sido publicado em francês nos Archives de Neurologie, no artigo em questão Freud segue algumas ideias de Pierre Janet sobre a concepção popular que se pode formar sobre o próprio corpo. Acerca das ideias sobre o inconsciente na clínica francesa do século XIX, inclusive as de Janet, mencionadas por Freud no texto, confira Cazeto (2001). Para uma visão abrangente sobre a história das concepções sobre o inconsciente e sua influência na psiquiatria, ver Ellenberger (1970); para um ponto de vista mais filosófico, confira Gödde (1999). Em termos mais específicos, porém, convém esclarecer que em suas elaborações metapsicológicas e na formulação do conceito de inconsciente, Freud sempre teve claras as diferenças entre sua concepção de inconsciente e as concepções correntes tanto na medicina, como na psicologia e filosofia da época. Com relação à concepção de inconsciente proposta por Theodor Lipps (1897/2001), em particular, o leitor pode verificar as considerações de Freud no capítulo 7 de $A$ interpretação dos sonhos, parte F, intitulada "O inconsciente e a consciência. A realidade", em que, após discutir a concepção de inconsciente de Lipps, conclui: "Não é sem intenção que digo em nosso inconsciente, pois o que assim chamamos não coincide com o inconsciente dos filósofos nem com o inconsciente segundo Lipps" (FREUD, 1900/1961, p.619, grifo no original). De modo análogo em relação ao termo subconsciente, esclarece ele: "Também da distinção entre supraconsciência e subconsciência, que permanece na bibliografia mais recente sobre as psiconeuroses, nós precisamos manter-nos distanciados, pois precisamente parece acentuar a equiparação do psíquico com o consciente" (FREUD, 1900/1961, p.620).
} 
por Freud também deveria, ao menos em princípio, permitir supor uma correspondência entre certos processos psíquicos inconscientes e diferentes formas de manifestação das perturbações neuróticas. Se antes a explicação dos sintomas observados no exame clínico remetia-se às alterações anatômicas, com o advento da psicanálise esta passa a referir-se aos processos psíquicos inconscientes.

\section{UMA VINHETA METAPSICOLÓGICA: O CONCEITO DE REPRESSÃO PRIMORDIAL E A GÊNESE DO INCONSCIENTE}

O conceito de repressão primordial é apresentado por Freud no contexto da teorização sobre a repressão propriamente dita [Nachdrängen]. Assim, visa oferecer uma fundamentação para esta que poderia ser denominada repressão secundária. De acordo com Freud, a experiência com as neuroses de transferência ensinou que: “a repressão não é um mecanismo de defesa existente desde a origem, que ela não pode nascer antes que se tenha produzido uma separação nítida entre atividade consciente e atividade inconsciente da alma [...]" (FREUD, 1915b/1967, p.249-50).

Deste modo, o conceito de repressão primitiva é forjado exatamente para dar conta desse momento inaugural em que se opera a divisão entre consciente e inconsciente, ao mesmo tempo em que serve para fundamentar o processo posterior da repressão propriamente dita, a secundária. Portanto, o conceito de repressão primordial designa um momento quase mítico, em que pela primeira vez o representante psíquico da pulsão [Triebrepräsentanz] é impedido de ter acesso à consciência ou à afetividade. "Com isso é dada uma fixação; o representante [Repräsentanz] em questão permanece a partir daí inalterado e a pulsão a ele ligada” (1915b/1967, p.250). A manutenção da fixação da pulsão ao seu representante ideativo seria resultado da ação de uma força que Freud chama de contrainvestimento [Gegenbesetzung], que visa impedir a satisfação pulsional. De maneira análoga à hipótese do Big-Bang na cosmologia física e o mito judaico-cristão do pecado original (MENAHEM, 2008), Freud teria forjado o conceito de repressão primordial para dar conta do momento em que seria estabelecida a primeira barreira a dividir um solo não apenas virgem, bruto, mas, sobretudo, não diferenciado até então. Dito de forma breve: não teria sido feita ainda a separação entre um inconsciente, por um lado, e um pré-consciente e consciente, por outro. Trata-se, portanto, da origem, da fundação, daquilo que será designado e definido pelo conceito de Inconsciente.

Não devemos nos esquecer aqui que é da natureza de uma pulsão - considerada um conceito fundamental da psicanálise, análogo aos conceitos fundamentais das demais disciplinas científicas, como a física (FREUD, 1915a/1967) - buscar sempre a satisfação. Por isso, diz Freud, “a repressão não impede o 
representante da pulsão de continuar existindo no inconsciente, de continuar a organizar, a formar novas representações derivadas e estabelecer ligações" (1915b/1967, p.251). Ao ser mantido fora da consciência, o reprimido passa a ter, no Inconsciente, maior liberdade de ação, pela simples razão de que aí não imperam as regras lógicas e morais da vida consciente, proliferando-se em formações psíquicas derivadas, substitutivas, enfim, emanações produzidas pela força compulsiva do reprimido. É o que nos esclarece Freud: “[...] o representante da pulsão [Treibrepräsentanz] se desenvolve de forma abundante e imperturbada quando ele, mediante a repressão, foi retirado da influência consciente. Ele então prolifera, por assim dizer, na escuridão e encontra formas extremas de expressão [...]" (1915b/1967, p.251).

Em outras palavras, os derivados do representante pulsional reprimido, as formações substitutivas, entendidas como um substrato fantasístico inconsciente, são compreendidas por Freud como ligações associativas altamente organizadas, que se encontram na base dos sintomas, sonhos e demais formações psíquicas. O trecho abaixo, de um psicanalista contemporâneo, vale como ilustração: "A fantasia é uma neblina interior que deforma a percepção da nossa realidade afetiva. Essa cena chama-se então fantasia inconsciente e impregna o corpo do sujeito, regula sua sensibilidade erótica e governa, à sua revelia, o conjunto dos comportamentos afetivos e mesmo sociais" (NASIO, 2005/2007, p.16).

O que nos interessa pôr em relevo é a dinâmica inconsciente, o movimento compulsivo de investimentos em representações que a conceituação freudiana faz supor e discernir como presente e em contínua operação no âmago da realidade psíquica. Dinâmica inconsciente esta que, ao mesmo tempo que está na base da determinação dos sonhos, sintomas e sofrimentos psíquicos de toda ordem, é-nos inteiramente alheia, desconhecida pela consciência, invisível e inaudível. Somente uma forma particular de escuta, dirigida para as incongruências e lacunas resultantes da intromissão desses conteúdos inconscientes junto aos processos psíquicos e comportamentais manifestos — aflorados na associação livre - é capaz de apreendê-los.

Por outro lado, da perspectiva conceitual que orienta nossa discussão sobre o Inconsciente, o analista, ou melhor, a imagem mnêmica ou representação do analista para o analisante pode ser capturada pela cadeia associativa das fantasias derivadas do reprimido e ser tomada como objeto de investimento libidinal. Isso correria porque, segundo Freud, “outra representação de meta em relação a qual o paciente não suspeita é a de minha pessoa” (1900/1961, p.537). Portanto, a situação clínica pode tornar-se um lugar privilegiado de busca de satisfação pulsional, um palco no qual pode desenrolar-se o drama fantasístico do analisante. Assim, vemos que, em seus fundamentos, o conceito de transferência compartilha os mesmos pressupostos e princípios sobre os quais se assenta a 
conceituação que dá sentido e organiza a realidade psíquica inconsciente construída por Freud. Dessa perspectiva, se entendermos por metapsicologia o conjunto das hipóteses e conceitos teóricos forjados por Freud para dar conta da realidade do Inconsciente e "fundamentar um sistema psicanalítico" (FREUD, 1917/1967, p.411, n.1), parece-nos lícito afirmar que a metapsicologia fundamenta a técnica. Senão vejamos.

Desde $A$ interpretação dos sonhos, de 1900, sabemos que Freud adota como fundamento da técnica as mesmas hipóteses metapsicológicas operantes na explicação dos sonhos e sintomas. Assim, duas proposições são apresentadas como os pilares [Grundpfeilen] da técnica da psicanálise.

Enumeramos as proposições para comentá-las a seguir: "[1] O domínio sobre o curso de representação, com o cancelamento das representações de meta [Zielvorstellungen] conscientes, passa para as representações de meta escondidas; e [2] as associações superficiais são apenas um substituto de deslocamento para associações suprimidas mais profundas” (FREUD, 1900/1961, p.537).

Os resultados do trabalho com as neuroses ensinam que no âmbito dos fenômenos psicopatológicos devem ser considerados dois níveis de ligações de pensamento, conforme estabelece a proposição [2], ou seja, um nível superficial e outro profundo. As ligações profundas representariam as ligações de pensamento realmente efetivas e relacionadas ao representante pulsional reprimido; as ligações superficiais seriam falsas, sintomas ou manifestações deformadas das primeiras, resultantes da ação da censura, que visaria impedir o acesso dos conteúdos reprimidos ao domínio da consciência. Por isso, à interpretação psicanalítica caberia buscar, sob tais ligações superficiais, as ligações profundas e efetivas; na linguagem de $A$ interpretação dos sonhos, a partir da análise do conteúdo manifesto tentar alcançar o conteúdo latente do sonho. De modo análogo, alguns anos após o trabalho sobre os sonhos, dirá Freud que "o sintoma histérico é a realização de uma fantasia inconsciente a serviço da realização do desejo" (1908/1966, p.196).

Com a primeira proposição [1], por sua vez, estaria teoricamente justificada a regra fundamental da "associação livre", pois à medida que a atenção ou controle consciente sobre o pensamento são retirados ou ao menos diminuídos, abrir-se-ia a possibilidade da ocorrência de pensamentos ligados ao desejo inconsciente. O elo necessário para se compreender esse processo é a noção de Zielvorstellung, representacão de meta ou de objetivo. Este gênero de representações compreende aquelas responsáveis por guiar o curso dos pensamentos ou associações. Para Freud (1900/1961, p.534), era inconcebível a suposição de cursos de pensamentos isentos de um governo por tais representações, sejam elas conscientes ou inconscientes. Em suma, com a noção de representação de meta, Freud não estaria senão dando corpo conceitual a uma pressuposição que 
já vinha utilizando há algum tempo, a do determinismo psíquico, ou seja, que "não há aí nada arbitrário" (1900/1961, p.519).

Se a técnica psicanalítica é fundamentada pela metapsicologia, quais mudanças na técnica poder-se-iam esperar das transformações que sofreu a metapsicologia com a virada dos anos 1920, com a introdução do conceito de pulsão de morte (FREUD, 1920/1967)? Afinal, depois de 1920, contamos com o reconhecimento explícito de Freud de que o Inconsciente não é constituído só pelo reprimido, como demonstrado pelo processo designado pela Urverdrängung, mas é também habitado por forças ainda mais poderosas, o Isso [Es] (FREUD, 1923/1967) e as fontes filogenéticas que se perderiam no passado da própria espécie humana. Ultrapassa o escopo deste trabalho, mas parece certo que essa nova maneira de conceber o Inconsciente tenha levado a uma reconsideração dos poderes da técnica psicanalítica, pois com a introdução dos conceitos de pulsão de morte e compulsão à repetição, Freud se vê obrigado a reconsiderar a questão da cura e ampliar a técnica psicanalítica: as construções em análise teriam valor apenas aproximativo (FREUD, 1937/1961). É notável, por outro lado, como tal guinada teórica assinala a reconciliação com algumas de suas intuições mais precoces e originais, já que desde os primórdios da metapsicologia Freud considerava que as cenas de sedução jamais teriam sido concretamente vivenciadas pela histérica (FREUD, 1986; carta de 21/09/1897), mas sua efetividade resultaria das deformações produzidas pelas fantasias emanadas do jogo pulsional inerente à realidade psíquica inconsciente.

\section{O(S) CONCEITO(S) DE INCONSCIENTE(S) E A(S) PRÁTICA(S) PSICANALÍTICA(S)}

De acordo com a perspectiva que compreende o Inconsciente como uma construção científico-conceitual aos moldes da ciência moderna - portanto, acessível apenas mediante a conceituação metapsicológica - , as intervenções e interpretações do analista dependem da maneira como ele concebe o espaço que se configura na situação clínica. Para levantar algumas questões sobre as implicações para a prática clínica decorrentes da concepção de Inconsciente que se adota, tomaremos por base algumas afirmações de dois psicanalistas contemporâneos, Jean Laplanche e Juan David Nasio. A contraposição de algumas afirmações desses dois autores revela que é a concepção particular sobre o Inconsciente que justifica e explica o modo igualmente particular com que um psicanalista concebe a prática clínica e faz uso da interpretação.

Notemos, de início, que ao longo da obra de Freud ganha força uma concepção realista do Inconsciente. Ou seja, para Freud o Inconsciente seria algo efetivamente existente e em operação em cada indivíduo. Basta recordar a concepção 
sistemática e genética de Inconsciente, presente nos textos sobre metapsicologia (FREUD, 1915b/1967, 1915c/1967). Com efeito, a situação analítica poderia ser concebida como configurada pelo encontro de dois Inconscientes, isto é, pelo encontro de duas paisagens interiores, cada uma das quais compreendidas por Freud na linguagem de um aparelho psíquico composto por sistemas ou instâncias e habitado por forças em conflito intrapsíquico (FREUD, 1900/1961; 1923/1967). Portanto, a situação analítica poderia ser configurada como o encontro de dois aparelhos psíquicos, e os fenômenos daí resultantes — como a transferência e a contratransferência - teriam sua explicação e justificação na própria conceituação que tematiza esse aparelho. Ilustremos a concepção de um Inconsciente individual por meio de uma afirmação de Laplanche:

"O inconsciente é individual; para ser escandaloso, eu diria que ele está na cabeça de cada indivíduo. O inconsciente é essa parte de sua história subtraída não só [...] ao tecido das significações convencionais, mas subtraída também a toda intenção de comunicação [… Somente a metodologia inventada por Freud — e não uma metodologia pretensamente orientada para o significante — , que alia indissoluvelmente livres associações e situação analítica, permite reabrir parcialmente, de um modo precário, de um modo sempre rediscutido, um inconsciente sempre prestes e pronto a se fechar de novo à comunicação, pois que esse fechamento é inerente à própria essência de sua constituição." (LAPLANCHE, 1981/1992, p.115)

Sem entrar em comentários adicionais sobre o Inconsciente, cuja gênese e essência analisamos em linhas gerais na seção 3, e que nos parece consistente com a afirmação de Laplanche, registremos apenas que, nessa perspectiva realista, o papel do analista é subentendido como o polo privilegiado da atividade analítica, o polo do trabalho de elaboração de interpretações e construções sobre o material aflorado nas livres associações produzidas pelo analisante.

Por outro lado, entre as afirmações de Nasio, o que chama inicialmente a atenção é sua posição em relação à maneira como entende a interpretação na situação analítica. Eis um de seus textos:

“A interpretação de que falo é impessoal. [...] Esses enunciados não são precedidos de nenhuma intenção calculada, da parte do analista, de provocar uma reação particular no paciente. Pelo contrário, são palavras ditas sem que o analista saiba. Em um momento dado eu dei uma fórmula: 'Quando o analista interpreta, não sabe o que diz'. E acrescentei: 'Ele pode não saber o que diz, com a condição de que saiba o que faz'. São, pois, palavras que irrompem subitamente no analista, que este pronuncia sem saber. Ele é ultrapassado pelo seu enunciado e, entretanto, são palavras esperadas, esperadas no contexto da sequência, da sessão, 
no momento em que o analista fala e, principalmente, esperadas pelo próprio analisando." (NASIO, 1999, p.143)

Para esse autor, o analista, ao interpretar, é atravessado por um enunciado que ele próprio desconhece. Será que ao afirmar que a interpretação "vem” ao analista sem que ele mesmo saiba, Nasio está supondo que não é o analista que a elabora mediante a escuta e o trabalho sobre as associações produzidas pelo analisante? Também, pelo fato de este autor considerar a interpretação algo impessoal e involuntário, a situação analítica parece não ser entendida como configurada pela relação entre dois aparelhos psíquicos, como a possibilidade antes cogitada. Dito de maneira direta, como pode o analista desconhecer as intervenções que faz? Assim, subentendida na concepção de Nasio parece haver uma maneira particular de compreender o Inconsciente e o papel do analista.

De fato, a opinião particular de Nasio sobre a interpretação e o papel do analista encontra sua justificação e explicação na concepção igualmente particular que este autor tem sobre o Inconsciente. Qual é essa concepção? Em virtude de nossos objetivos, aqui lançaremos mão apenas de algumas passagens de seu seminário sobre a teoria de Lacan (NASIO, 1992/1993), nas quais comenta o assunto. Para ele, o Inconsciente não tem existência própria como algo oculto aguardando por "uma interpretação que venha revelá-lo"; quer dizer, não haveria um Inconsciente individual, como somos levados a conceber ao ler os textos de Freud e Laplanche. É o que afirma o autor: “[...] não existe um inconsciente pertencente ao analisando e, depois, um outro inconsciente pertencente ao psicanalista [...]” (idem, p.51). Mas, então, para Nasio, não existiria o Inconsciente? Naturalmente que sim, mas, para ele, só há inconsciente no campo da análise, porque o inconsciente é "uma instância produzida quando a interpretação do analista, considerada como um ato de seu inconsciente, reconhece o ato do inconsciente do analisando" (idem). Quer dizer, a interpretação entendida como ato próprio ao analista é que faz nascer, é que produz essa instância chamada por ele Inconsciente. E por ser essa instância produzida pela interpretação é que, na perspectiva de Nasio, não faz mais sentido afirmar que na situação analítica temos o encontro de dois Inconscientes, ou dois aparelhos psíquicos, como assinalamos ao comentar a posição de Laplanche. "O inconsciente é uma estrutura única, comum a ambos os parceiros analíticos, $[. .$.$] há apenas um único inconsciente,$ o que é produzido e é singular no seio da transferência” (idem), termina por afirmar nosso autor. Cumpre registrar, como o faz o próprio Nasio, que essa não é precisamente a concepção de Lacan. Escreve ele: “Faço questão de deixar claro que essas proposições resultam de minha leitura da obra lacaniana, mas nunca foram enunciadas por Lacan” (1992/1993, p.50). 
Mas Nasio não se dá por satisfeito. Em texto mais recente ele continua a desenvolver a ideia de um Inconsciente único, produzido na transferência, e acaba por considerar a própria situação analítica como um único e grande aparelho psíquico. Reconhece não ser esta a maneira usual de se referir ao aparato conceitualmente construído por Freud. Em suas palavras:

“Essa forma de considerar o aparelho psíquico como uma instância comum ao analisando e ao psicanalista é uma hipótese que defendi pela primeira vez em 1976. Desde então, não cessei de reformular a mesma tese, mas considerada sob diferentes ângulos. Ela é o oposto da noção corriqueira, que concebe o inconsciente como uma instância individual própria de cada um." (NASIO, 2005/2007, p.101)

Temos, portanto, não apenas dois conceitos distintos de inconsciente, mas também implicações daí decorrentes para a maneira de entender a configuração do que seja a situação analítica, a saber: uma que a concebe como o encontro de dois Inconscientes, ou dois universos fantasísticos próprios, o do analisante e o do analista; outra, que a concebe como dando suporte a um Inconsciente único, entendido como a trama fantasística inconsciente aflorada na transferência, porque produzida não simplesmente pelo encontro entre analisante e analista, mas por um ato do analista, um ato interpretativo. Parece que de cada uma dessas concepções de Inconsciente e da situação clínica decorrem duas formas distintas de prática analítica.

Tomando a interpretação como exemplo, poderíamos considerar que o modo particular com que Nasio a concebe só pode encontrar justificativa e explicação no modo também próprio pelo qual concebe a realidade psíquica inconsciente. Quer dizer, se há um único Inconsciente, de fato, faz sentido afirmar que o próprio analista pode ser atravessado por emanações provenientes desse espaço analítico inconsciente. A interpretação pode vir ao analista sem que ele mesmo se dê conta. Por outro lado, do ponto de vista de Freud e Laplanche, parece-nos que a interpretação e as construções supõem um trabalho efetivo por parte do analista. Basta recordar a correlação entre trabalho do sonho e trabalho de interpretação, em que à interpretação do analista caberia desfazer as deformações produzidas pelo trabalho do sonho. O advento das construções em análise não modificaria substancialmente esse posicionamento do analista; ao contrário, parece exigir dele muito mais trabalho analítico.

\section{CONSIDERAÇÕES FINAIS}

Para não finalizar este trabalho de forma maniqueísta, retomamos a discussão sobre a repressão primordial. Se levarmos em conta a fixação pulsional e a 
proliferação de derivados ou formações psíquicas substitutivas, levadas a efeito pela força do desejo reprimido, parece que independentemente do conceito de Inconsciente que se abrace, o trabalho de escuta do analista é sempre orientado para as livres associações produzidas pelo analisante. Além disso, as associações livres são, em ambas as perspectivas, sempre vinculadas à situação analítica, ou seja, à transferência. Para Nasio essa é uma condição necessária, pois o Inconsciente brota na/da transferência, mas é também fundamental para a perspectiva freudiana/laplancheana. Basta recordar a afirmação de Laplanche: "Somente a metodologia inventada por Freud [...] que alia indissoluvelmente livres associações e situação analítica permite reabrir parcialmente [...] um inconsciente sempre prestes e pronto a se fechar de novo à comunicação [...]” (1981/1992, p.115). Enfim, parece-nos que não importa qual seja a concepção de Inconsciente que se adote: a matéria-prima sobre a qual o analista trabalha é sempre dada nas/pelas livres associações do analisante, associações estas que não são senão formas derivadas, formações substitutivas, prolongamentos desfigurados de fantasias inconscientes, cujas raízes podem, para Freud, ancorar-se no reprimido ou perderem-se em elos filogenéticos. Portanto, em ambos os casos, as associações não florescem senão no solo fértil da transferência.

Em relação ao enigma da interpretação que "vem” ao analista, certamente, aceitar essa possibilidade implica não no abandono da racionalidade conceitual, mas no reconhecimento de uma racionalidade inconsciente, isto é, no reconhecimento do limite em que a racionalidade psicanalítica se depara com o próprio umbigo. Afinal, em seus conselhos ao médico sobre o tratamento psicanalítico, mesmo Freud já admitia a possibilidade de uma comunicação entre Inconscientes. Dizia ele em uma fórmula:

“Ele deve direcionar ao Inconsciente emissor do doente o seu próprio Inconsciente como órgão receptor, colocar-se para o analisante como o receptor do telefone se coloca para o transmissor. Como o receptor transforma as oscilações elétricas das ondas sonoras recebidas novamente em ondas sonoras, assim o inconsciente do médico está capacitado a, desde os derivados do inconsciente a ele comunicados, reconstruir [wiederherzustellen] esse inconsciente que determinou as ocorrências [Einfälle] do paciente.” (FREUD, 1912/1964, p.381)

Portanto, se mantivermos em nosso espírito que todo o esforço de Freud consistiu em reconduzir o desconhecido ao conhecido, em tornar racional o irracional, consciente o Inconsciente, talvez possamos compreender a posição de Nasio frente à interpretação não como um enigma ou um disparate, mas como expressão de um esforço e risco na exploração de algo como um umbigo da teoria e da técnica psicanalíticas. 
Resta saber, enfim, que teoria fundamenta nossa técnica, porque, como escreve Hornstein, não se trata de fazer da teoria um fetiche, mas se "os clínicos se satisfazem com fórmulas metapsicológicas simples (uma metapsicologia portátil), indispensáveis para poder operar tecnicamente" e deixam o estudo dos conceitos nas mãos dos filósofos e epistemólogos, "é óbvio que a prática se converte em um artesanato mais ou menos empírico" (1988/1990, p.106). Em outras palavras, resta saber qual metapsicologia habita o lugar de analista e orienta não apenas nossa compreensão da realidade psíquica inconsciente, mas, sobretudo, nossa prática clínica.

Recebido em 26/4/2010. Aprovado em 11/8/2010.

\section{REFERÊNCIĀS}

CAZETO, S. J. (2001) A constituição do inconsciente em práticas clínicas na França do século XIX. São Paulo: Escuta.

CHALMERS, A. F. (1976/1982) O que é ciência afinal? São Paulo: Brasiliense. ELIA, L. (2004/2007) O conceito de sujeito. Rio de Janeiro: Zahar.

ELLENBERGER, H. F. (1970). The discovery of the unconscious. The history and evolution of dynamic psychiatry. New York: Basic Books.

FREUD, S. (1961-1967) Sigmund Freud Gesammelte Werke. Frankfurt am Main: S. Fischer.

(1893/1964) “Quelques considérations pour une étude comparative des paralysies motrices organiques et hystériques”, v.I, p.37-55.

(1900/1961) “Die traumdeutung”, cap.7, v. II, p.513-626.

(1908/1966) "Hysterische phantasien und ihre beziehung zur bissexualität”, v.VII, p.189-199.

(1912/1964) "Ratschläge für den arzt bei der psychoanalytischen behandlung”, v.VIII, p.375-387.

(1915a) “Triebe und triebschicksale”, v.XI, p.209-232.

(1915b/1967) “Die verdrängung”, v.X, p.247-261.

(1915c/1967) “Das unbewusste”, v.X, p.263-303.

(1917/1967) “Metapsychologische ergänzung zur traumlehre”, v.X, p. $412-426$.

(1920/1967) “Jenseits des lustprinzips”, v.XIII, p.01-69.

(1923/1967) “Das ich und das es”, v.XIII, p.235-289.

(1933/1961) “Warum krieg?”, v.XVI, p.10-27.

(1937/1961) “Konstruktionen in der analyse”, v.XVI, p.41-56.

(1986) Sigmund Freud briefe an Wilhelm Fliess, 1887-1904. Frankfurt am Main: S Fischer.

GÖDDE, G. (1999) Traditionslinien des “Unbewussten”. Schopenhauer — Nietzsche - Freud. Tübingen: Edition Diskord.

HORNSTEIN, L. (1988/1990) Cura psicanalítica e sublimação. Porto Alegre: Artes Médicas. 
JONES, E. (1953/1989) A vida e a obra de Sigmund Freud. Rio de Janeiro: Imago.

KOYRÉ, A. (1957/s. d.) Do mundo fechado ao universo infinito. Lisboa: Gradiva.

LAPLANCHE, J. (1981/1992) O inconsciente e o id. São Paulo: Martins Fontes.

. \& PONTALIS, J.-B. (1967/2001) Vocabulário de psicanálise. São Paulo: Martins Fontes.

LIPPS, T. (1897/2001). O conceito de inconsciente na psicologia, Revista de Filosofia e Psicanálise Natureza Humana, 3(1), 335-356.

MENAHEM, R. (2008) "Le refoulement originaire", in BOUHSIRA, J.; DANON-BOILEAU, L. \& JANIN, C. (Orgs.) Le refoulement. Paris: PUF, p. 55-73.

NASIO, J. D. (1992/1993). Cinco lições sobre a teoria de Jacques Lacan. Rio de Janeiro: Zahar.

(1999). Como trabalha um psicanalista. Rio de Janeiro: Zahar.

(2005/2007). Fantasia. Rio de Janeiro: Zahar.

SOUZA, P.C. (1998) As palavras de Freud. O vocabulário freudiano e suas versões. São Paulo: Ática.

STRACHEY, J. (1962/1973). Editor's note to abstracts of the scientific writtings of Dr. Sigm. Freud 1877-1897, The Standard Edition of the Complete Psychological Works of Sigmund Freud, v.3, p.225-257. Londres: The Hogarth Press.

. (1966/1971) "Editor's note to some points for a comparative study of organic and hysterical motor paralyses", in The Standard Edition of Complete Psychological Works of Sigmund Freud. v.1, p.157-172. Londres: The Hogarth Press.

Helio Honda

hhonda@uem.br 